Agro Ekonomi Vol. 28/No. 2, Desember 2017

\title{
DETERMINANT FACTORS OF FOOD SECURITY IN INDONESIA
}

\section{Faktor Faktor yang Mempengaruhi Ketahanan Pangan di Indonesia}

\author{
Arif Wahyu Widada ${ }^{1}$, Masyhuri² ${ }^{2}$ Jangkung Handoyo Mulyo ${ }^{2,3}$ \\ ${ }^{1}$ Master Student of Agricultural Economics, Faculty of Agriculture, UGM \\ ${ }^{2}$ Faculty of Agriculture, UGM Jl. Flora No. 1 Bulaksumur, Yogyakarta \\ ${ }^{3}$ Center of Population and Policy Studies UGM J1. Tevesia, Bulaksumur, Yogyakarta \\ arif.w.widada@gmail.com
}

Diterima tanggal : 3 Juli 2017 ; Disetujui tanggal : 28 September 2017

\begin{abstract}
All countries around the world are dealing the same problem in assuring the sufficiency of food for feeding their people. Indonesia is the biggest agrarian state in South East Asia and the fourth largest state in the world. The challenge faced by Indonesia with a large population is on how food meets the needs of its population, which until now Indonesia has not been able to guarantee the fulfillment of food supply for its population. This study aims to analyze the influence of determinant factors toward Indonesian food security. Binary Logit Model was employed to analyze determinant factors of Indonesian food security. Jonsson and Toole criterion of food security was used to identify Indonesian food security status as dependent variable. This research found that land area, rice production, corn production, soybean production, chicken meat production, beef production, the population density the CPI (Customer Price Index) including the CPI for housing, electricity and gas, the CPI for health, the CPI for transportation and financial services, and FIMI (Food Insecurity Multidimensional Index) have significant influences towards the level of food security in Indonesia. It means that food security could be achieved by not only improving the quantity and quality of consumption, but also improving food supply, the ability to access economically and the stability.
\end{abstract}

Keywords : Binary Logit Model, Indonesian Food Security, Jonsson and Toole

\section{INTISARI}

Saat ini setiap negara di dunia sedang menghadapi kendala yang sama dalam memastikan kecukupan pangan untuk masyarakatnya. Indonesia adalah negara agraris terbesar di Asia Tenggara dan merupakan negara yang memiliki populasi penduduk terbesar ke 4 di dunia. Masalah yang dihadapi Indonesia dengan jumlah penduduk yang besar adalah bagaimana pangan yang tersedia di negara tersebut dapat memenuhi kebutuhan penduduknya akan pangan itu sendiri, dimana sampai saat ini Indonesia belum dapat menjamin seratus persen pemenuhan kebutuhan pangan tersebut dapat tercukupi. Penelitian ini bertujuan untuk mengetahui pengaruh dari beberapa faktor terhadap ketahanan pangan Indonesia. Binary Logit Model digunakan dalam penelitian ini untuk menganalisis faktor-faktor yang berpengaruh terhadap ketahanan pangan Indonesia. Kriteria Jonsson and Toole digunakan untuk menentukan ketahanan pangan sebagai variabel terikat. Hasil dari penelitian ini dengan menggunakan Binary Logit Model diketahui bahwa beberapa variabel seperti luas areal sawah, produksi jagung, 
produksi kedelai, produksi daging ayam, produksi daging sapi, kepadatan penduduk, Indeks Harga Konsumen untuk perumahan, listrik, dan gas, Indeks Harga Konsumen untuk kesehatan, Indeks Harga Konsumen untuk transportasi dan jasa keuangan, dan FIMI mempunyai pengaruh signifikan terhadap ketahanan pangan Indonesia. Hal ini menunjukkan bahwa ketahanan pangan tidak hanya dapat diwujudkan dengan meningkatkan kuantitas dan kualitas dalam pemanfaatan pangan, tetapi juga dengan memperbaiki pasokan pangan, kemampuan mengakses secara ekonomi dan kestabilan pangan seiring berjalannya waktu.

Kata kunci : Binary Logit Model, Jonsson and Toole, Ketahanan Pangan Indonesia

\section{INTRODUCTION}

Food is part of human rights related and regulated in Indonesian Food Law, "Undang-undang tentang Pangan" No. 18 of 2012. Based on the regulations, food becomes the main basic need to realize qualified human resources. The use of food will reflect the nutritional status of the individual and then affect the welfare of one's productivity in generating income. Food security is a growing concern worldwide for decade. More than 1 billion people are estimated to lack sufficient dietary energy availability, and at least twice that number suffer micronutrient deficiencies. Because indicators inform action, much current research focuses on improving food insecurity measurement. Yet estimated prevalence rates and patterns remain tenuous because measuring food security, an elusive concept, remains difficult (Barret, 2010).

Sufficient food for the population is highly regarded in national development. Therefore, food security is important to be realized in ensuring the fulfillment of food needs for the sustainability of a country's population. The World Food Summit states that food security occurs when all people constantly, physically, socially, and economically have access to adequate or adequate, nutritious and safe food, which meets their food needs and food choices to live actively and healthy (Food Security Council RI, 2009).

The requirements to achieve national food security are the availability of adequate quantities of food and meet the nutritional requirements of the population. Foods that can be produced domestically are sought to remain the main pillars in the national food supply, as they are related to the realization of national food security and sovereignty (Lantarsih et al, 2011).

Food in the hierarchy of human needs is the ultimate necessity so that fulfillment becomes the basic right of everyone. Food security is the main pillar in national development which is very synonymous with national security and cannot be negotiable. President of the United States, George W. Bush, in his speech at Future 
Farmer of America July 27, 2001 stated: a country that was unable to grow enough food to feed the people would be a nation subject to international pressure. It would be a nation at risk (Nanggolan, 2007).

Reflecting on history, the problems posed by food not only have a negative impact on socio-economic conditions, but also can lead to political instability. For example, there are problems caused by food in different parts of the world. The unrest occurred in West Africa in 2007-2008 due to rising food prices and higher tax levies caused by the food crisis, accompanied by protests and demonstrations due to rising poverty levels, as happened in Egypt, the Middle East and North Africa. Violence also occurred which resulted in the deaths of 100 people and the arrest of 1,671 people resulting from price inflation and food shortages in Cameron (Bush, 2010). It will be possible that Indonesia will experience a similar incident if this food issue is ignored. This is because Indonesia has an increasing population growth with an average of $1.56 \%$ per year (BPS, 2013) and is the fourth largest contributor to the world population until 2016 after China, the United States and India.

Food problems at the national level related to economic stability for the population and national security. Food that is difficult to obtain can be caused by several factors, such the number of national food availability, food distribution, food quality, and the price of food that is still unaffordable for various layers of society. Food security for households means access by all members at all times to adequate food for an active healthy life. Minimal food security includes providing nutritious and safe food, and the ability to ensure that food is socially acceptable (i.e. without the use of emergency food, scavenging activities, stealing or other handling strategies). Apart from food production, food accessibility is essential to achieve food security. Food security at the national level does not cover the whole community, especially the poor. The poor have minimum access to nutritional needs due to regional, economic and social inequalities. There is food insecurity in some rural populations because they do not produce enough food and or do not have enough purchasing power to meet their dietary needs. (Omotesho et al., 2010).

The humanity in the worldwide level is facing severed nutritional imbalances depending on access to food and the dietary habit of particular population that can make them suspected to malnutrition (Abbade, 2015). Related to the food access, it is positively affected by changing of food prices. The policy taken by the government on food prices including export and import will derive welfare impact to the people ability to access enough food (Groom, 2015).

Mulyo et al., (2015) said that food security and food self-sufficiency at 
household level are much determined by their farm production. Meanwhile, some areas considered as the marginal area are constrained by limited support of natural resources. Thus, many households lived in marginal area will face food insecurity. This study aimed to understand the households' food security level, both measured by using the Energy Sufficiency Score (AKE) and the Food Expenditure Share (PPP). Furthermore, this study also tries to identify the food self-sufficiency level among rural marginal household in Bojonegoro Regency and also used cross classification of food security levels based on Jonnson and Toole (1991) in Maxwell et al., (2000). The result of study shows that there is a wide disparity among rural household in the food/energy intake, this is shown by the average level of food/energy intake level that is considered high (87\%), meanwhile there is $53 \%$ of the households categorized as the food insecure household. Based on the Food Expenditure Share level, most of the households are categorized as food secure households. The food selfsufficiency, particularly rice, has been attained. Measured as the ratio of calorie availability to domestic demand we note that food security at the national level has improved and appears to be stable over time. (Saliem et al., 2003)

Based on these problems, it becomes very important to know the factors affecting food security in Indonesia considering that
Indonesia is a country with agriculture sector that is one of the leading sectors in the economy and the only sector that can provide food for everyone. The purpose of this study is to analyze the factors that affect the food security of Indonesia.

\section{METHODS}

The data used in this study were secondary data, including production data, productivity, harvested area, paddy field area, consumption, price, population, poverty data and others on every province in Indonesia obtained from several publications of Indonesian Statistics Bureau (BPS), Ministry of Agriculture Database, and other sources in various years. The type of data used was panel data. Panel data was a composite data type of cross section and time series data. Cross section data in this research are 33 provinces in Indonesia (North Kalimantan Province was still combined with East Kalimantan Province due to availability of series data) with its time series from 2007 to 2014 for each variable used.

\section{Analysis Method}

The method used to find out the determination factors influencing Indonesian food security was Binary Logit Model. Binary Logit Model used two types of variable those were response variable or dependent variable (food endurance level through Jonsson and 
Table 1. The Level of Food Security based on Jonsson and Toole Classification with some modification

\begin{tabular}{|c|c|c|}
\hline \multirow[b]{2}{*}{ Calorie Intake } & \multicolumn{2}{|c|}{ Proportion of Food Expenditure (PFE) } \\
\hline & $\begin{array}{c}\text { Low } \\
(<60 \% \text { of total expenditure })\end{array}$ & $\begin{array}{c}\text { High } \\
(\geq 60 \% \text { of total expenditure) }\end{array}$ \\
\hline $\begin{array}{l}\text { Sufficient (>80\% } \\
\left.\text { from } \mathrm{AKE}^{*}\right) \text { Not }\end{array}$ & $\begin{array}{l}\text { Food Secure } \\
\text { (food secure) }\end{array}$ & $\begin{array}{l}\text { Food Vulnerable } \\
\text { (food insecure) }\end{array}$ \\
\hline $\begin{array}{c}\text { Sufficient }(\leq 80 \% \\
\text { from AKE* })\end{array}$ & $\begin{array}{l}\text { Food Less Secure } \\
\text { (food insecure) }\end{array}$ & $\begin{array}{l}\text { Food Insecure } \\
\text { (food insecure) }\end{array}$ \\
\hline
\end{tabular}

Source: Modified from Maxwell et al. (2000).

*AKE is Standard Indonesian Energy Sufficiency from food consumption equal to 2.150 $\mathrm{kkal} / \mathrm{capita/days.}$

Toole cross classification) and independent explanatory (Independent variables) were some variables that allegedly affect the level of food security in Indonesia.

Jonsson and Toole (1991) in Maxwell et al., (2000) classify the level of household food security into four categories: food secure, food less secure, food vulnerable and food insecure by combining the proportion of food expenditure with energy sufficiency. The grouping was based on consideration of economic and household nutrition aspects. From the economic aspect, it was measured from the proportion of food expenditure to the total expenditure of the households, while the nutritional aspect was measured based on the fulfillment of the adequacy of food consumption in the energy unit. The restriction used was the proportion of food expenditure $60 \%$ of the total household expenditure and $80 \%$ of the energy adequacy (showed on the Table 1).
Binary Logit Model was used for the case of regression equation with Qualitative Response Variable. Qualitative data used in this study was the level of food security divided into 2 categories those are food secure and three next categories as food insecure as dependent variable. Based on the above description, the regression equation used in this study followed equation below.

Food Security:

$\mathrm{Y}^{*}=1 ;$ Food Secure

0; Food Insecure (food less, secure, food vulnerable, food insecure)

Multiple logistic regression model was logistic regression model for several variable of predictor $\mathrm{X}$ with $\mathrm{Y}$ as response variable according to dichotomy. The variable value $\mathrm{Y}=1$ represents the presence of a characteristic and $\mathrm{Y}=0$ indicates the absence of a characteristic. According to Hosmer and Lemeshow (1989), Logistic 
regression model was influenced by $\rho$ predictor variable which could be expressed as the expected value of $\mathrm{Y}$ with value $\mathrm{x}$ :

$E(Y \mid x)=\frac{e^{\left(\beta_{\mathrm{o}}+\sum_{k=1}^{p} \beta_{k} \cdot x_{k}\right)}}{1+e^{\left(\beta_{\mathrm{o}}+\sum_{k=1}^{p} \beta_{k} \cdot x_{k}\right)}}$

With $0 \leq E(Y \mid x) \leq 1$ and $\mathrm{Y}$ had a value of 0 or 1 . The value of $E(Y \mid x)$ was a probability of success, so it could be expressed by $p(\mathrm{x})$, so the equation became,

$p(x)=\frac{e^{\left(\beta_{0}+\sum_{k=1}^{p} \beta_{k} \cdot x_{k}\right)}}{1+e^{\left(\beta_{0}+\sum_{k=1}^{p} \beta_{k} \cdot x_{k}\right)}}$

With $\beta k$ denoted the regression parameters, $x k$ was observed the k-predictor variable of a predictor variable $p$. Logit transformation was applied to the logistic regression model,

$\operatorname{Logit}(p(x))-g(x)=\ln \left[\frac{p(x)}{1-p(x)}\right]$

$=\beta_{0}+\sum_{k=1}^{p} \beta_{k} \cdot x_{k}$

Logit transformation was needed to create a linear function of its parameters. The function $g(x)$ was linear to the parameter and had range $(-\infty, \infty)$, depended on the range of the predictor variable $X$. The panel data regression equation of determinant factor of Indonesia food security in this second destination was as followed:

$$
\begin{aligned}
& \text { food_security }_{i t}=\beta_{0}+\beta_{1} \text { area_padfield }_{i t} \\
&+\beta_{2} \text { prod_padd }_{i t}+\beta_{3} \text { prod_maize } \\
&+\beta_{4} \text { prod_soy }_{i t}+\beta_{5} \text { prod_cass }_{i t} \\
&+\beta_{6} \text { prod_chicken }_{i t}+\beta 7 p r o d \_b e e f_{i t} \\
&+\beta_{8} \text { percent_unemployment } \\
&
\end{aligned}
$$

$$
\begin{aligned}
& +\beta_{9} \text { density_population }_{i t} \\
& +\beta_{10} \text { poor_number }{ }_{i t}+\beta_{1 l} \text { grdp_cap }{ }_{i t} \\
& +\beta_{12} \text { protein }_{i t}+\beta_{13} \text { cpi_foodstuff }{ }_{i t} \\
& +\beta_{14} \text { cpi_food }_{i t}+\beta_{15} \text { cpi_house } \\
& \text { electricity_gas }{ }_{i t}+\beta_{16} \text { cpi_clothes }{ }_{i t} \\
& +\beta_{17} \text { cpi_health }+\beta_{18} \text { cpi_edu_ } \\
& \text { sport_recre }{ }_{i t}+\beta_{19} \text { cpi_trans_ } \\
& \text { services_finance }{ }_{i t}+\beta_{20} i F I M I_{i t}+\varepsilon_{i t}
\end{aligned}
$$

with:

food_security =food security status, 1 is food secure and 0 is food insecure; $\beta=$ regression coefficient;

area_padfield = farm land area (hectare); prod_paddy = production of rice (ton); prod_maize $=$ production of maize (ton); prod_soy = production of soy bean (ton); prod_cass = production of cassava (ton); prod_chicken= production of chicken (ton); prod_beef $=$ production of beef (ton); percent_unemployment $=$ percentage of unemployment (\%);

density_population $=$ population density (person per $\mathrm{km}^{2}$ );

poor_number = number of poor (person); grdp_cap $=$ Gross Regional Domestic Product per capita (million/capita); protein $=$ consumption of protein $(\mathrm{gram} /$ capita/day);

cpi_foodstuff $=$ consumer price index for foodstuff;

cpi_food = consumer price index for food; cpi_house_electricity_gas = consumer price index for house, electricity, and gas;

cpi_clothes $=$ consumer price index for clothes;

cpi_health $=$ consumer price index for health;

cpi_edu_sport_recre= consumer price index for education, sport, and 
recreation;

$$
\begin{aligned}
& \text { cpi_trans_services_finance }=\text { consumer } \\
& \text { price index for transportation, } \\
& \text { services, and finance } \\
& \text { FIMI = Food Insecurity Multidimensional } \\
& \text { Index } \\
& \mathrm{I} \quad=\text { province-i } \\
& \mathrm{T} \quad=\text { year-t } \\
& \varepsilon \quad=\text { error }
\end{aligned}
$$

Model testing should be done to determine the accuracy of the model that was the factors affected Indonesian food security. A good model would create a precise estimation that can be used as an estimation to improve Indonesian food security. Musafak (2012) argued that logistic model equations did not assume linear relationship between independent variables and dependent variables, so no normality assumption was required on the distribution of variables and also homoscedasticity of variance. There were some principal differences for model testing between OLS and BLM.

\section{Goodness of Fit Test}

If the Hosmer and Lemeshow test was met, then the model was able to predict the observed value or it could be said that the model was acceptable because it was in accordance with the observation data written with the $\hat{C}$ test, calculated based on probability estimates (Hosmer and Lemeshow, 1989). Hosmer and Lemeshow test statistics $\hat{C}$ calculated based on value $\mathrm{y}=1$ formulated:

$$
\hat{\mathrm{C}}=\sum_{r=1}^{g} \frac{\left(o_{r}-n_{r} \mathrm{P}_{1 r}\right)^{2}}{n_{r} \mathrm{P}_{1 r}\left(1-\mathrm{P}_{1 r}\right)}
$$

With $\mathrm{P}_{1 r}$ denoted the average estimation probability of success for the $\mathrm{r}^{\text {th }}$ group, $o_{r}$ was the number of successful event samples in the $\mathrm{r}^{\text {th }}$ group, $\mathrm{n}_{\mathrm{r}}$ was the total sample of the $\mathrm{r}^{\text {th }}$ group, and $\sum_{r=1}^{g} n_{r}=n$ with $\mathrm{r}=1,2, \ldots$, g. Statistic test of $\hat{C}$ approached the distribution of Chi-Square with degrees of freedom g-2 (Hosmer and Lemeshow, 1989).

\section{Coefficient Determination (Overall of} Fit)

The value of Cox and Snell's R Square and Nagellkerke's R Square showed how much variability of dependent variables could be explained by independent variables (Bayaga, 2010). The coefficient of determination $\left(\mathrm{R}^{2}\right)$ was a modification of Cox \& Snell R Square which produced values between 0 and $1 . \mathrm{R}^{2}$ belonged to Nagelkerke (1991) was the most widely used as the basis of interpretation.

\section{LR Test with Omnibus Test of Model Coefficient}

In the OLS, the LR test was the same as the F test. The LR test was used to determine the effect of the independent variables simultaneously on the dependent variable. The LR formulations were as followed (Gujarati and Porter, 2009): 
$L R_{\text {stat }}=-2 \ln \left[\frac{L(\text { Mintercept })}{L(\text { Mfull })}\right]$

$M_{\text {intercept }}$ was a regression model containing intercept only (without variables), whereas $M_{\text {full }}$ was a regression model by including all variables to be tested for significance. The calculation result of $\mathrm{LR}_{\text {stat }}$ followed the distribution of Chi Square $\left(\chi^{2}\right)$ with degrees of free $\mathrm{p}$ or $\mathrm{LR}_{\text {stat }} \sim \chi^{2}(\mathrm{p})$.

\section{Wald Test(Z)}

Wald test was intended to determine the influence of independent variables partially to the dependent variable. Wald test in logistic model was similar to t test on OLS. However, Wald test used z-stat for decision making. The Wald test equation was as followed (Enisan, 2009):

$Z=\left[\frac{\widehat{\beta J}}{S E(\beta j)}\right]^{2}$

The value of $\mathrm{Z}$ followed the distribution of Chi Square $\left(\chi^{2}\right)$ with degrees $\mathrm{k}, \mathrm{Z} \sim \chi^{2}(\mathrm{p}$

\section{Interpretation of the Parameters}

In the logistic regression model, the parameter interpretation aimed to find out the meaning of the parameter estimation value in the predictor variable. There were two types of predictor variables $(\mathrm{Y})$, which were categorical variables and continuous variables. The way used to interpret logistic regression parameters from categorical variables was by odds ratios (Hosmer and Lemeshow, 1989).

Odds was the proportion of probability of a successful event with an unsuccessful event in a category. Odds for $x=1$ and $x=0$ were respectively:

$\frac{p(1)}{1-p(1)}$ and $\frac{p(0)}{1-p(0)}$

The odds ratio was the ratio of the odds value for category $x=1$ to the odds for category $x=0$, in the same predictor variable assuming the other predictor variable was constant. The odds ratio was expressed by $\psi$ and was written as:

$\Psi=\frac{\left\lfloor\frac{p(1)}{1-p(1)}\right\rfloor}{\left\lfloor\frac{p(0)}{1-p(0)}\right\rfloor}$

The presence of the variable $x$ with value 1 would gave the value of $\psi$ times than $x$ with value 0 to produce the success event $Y=1$. The way used to interpret the logistic regression parameters of the continuous variable was to assume a linear logit function against the predictor variable. Suppose the continuous predictor variable, and the function $g(x)=\beta_{0}+\beta_{1} x_{1}$, the interpretation of $\beta_{1}$ had properties equal to the parameters in the linear regression. Each increased of one-unit $\mathrm{x}$, the value of $g(x)$ rised by $\beta_{1}$, could be expressed by $\beta_{1}=g(x+1)-g(x)$ for each value of $x$. 


\section{RESULTS AND DISCUSSION}

\section{Food Security Level of Indonesia}

The determination of food security with cross-classification of Jonsson and Toole was divided into 2 parts: crosssectional classification of calorie intake and share of food expenditure from 2007 to 2010 and from 2011 to 2014. This clustering was to find further evidence of how the development of food security by province in Indonesia. Figure 1 shows that the majority of people residing in various provinces in Indonesia are on food secure criteria with up to $80 \%$ calorie intake and having a share of food expenditure of less than $60 \%$. There is only one province that enters into the food-vulnerable criteria of Aceh Province. The province already has an energy uptake of more than $80 \%$, but still has a share of food income above $60 \%$. This tells us that most of the population in Aceh Province

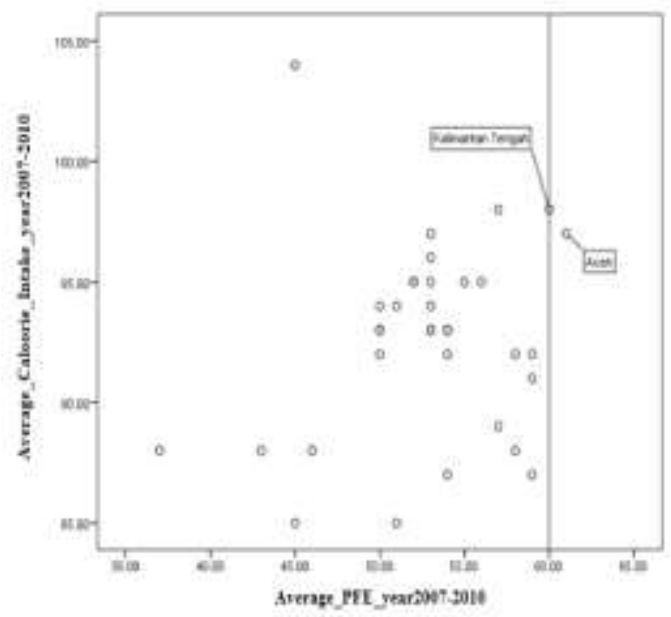

has been getting enough food, but this food still has to be redeemed with considerable effort. The province of Central Kalimantan has entered the criteria of food security, but the province has a tremendous opportunity to become vulnerable to food. That is, economic turmoil such as income sources and price changes can easily decrease the food security status of their communities.

Figure 1 is clearly shown that there is a decline in the quality of food security levels in most provinces in Indonesia. If in the average period of 2007 to 2014 there is only one province that entered into the criteria of food vulnerable, in the average period of 2011 to 2014 there are almost more than half of Indonesia is not food secure status. The provinces of East Kalimantan, Papua and North Maluku are included in the criteria for lack of food. That is, in the three provinces the

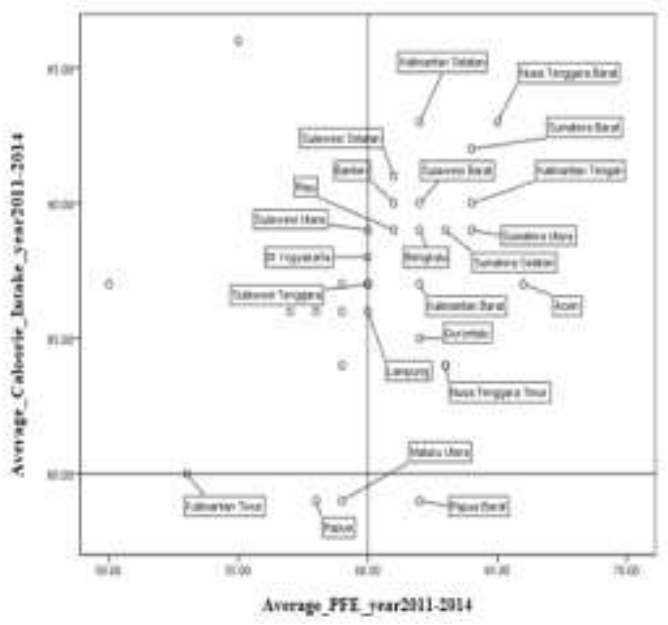

Figure 1. Cross Classification of Indonesian Jonsson and Toole Food Security Level by Province based on Average Data of Calorie Intake and PFE (Proportion of Food Expenditure) Year 2007-2010 and 2011-2014 Source: Analysis of secondary data, 2017. 
majority of people still consume food with less calorie intake, this could be due to lack of public awareness of adequate food consumption of energy uptake. In fact, West Papua Province entered into the criteria of food insecurity that is the lowest level of food security. This may be due to poor food quality and also low economic ability to access food for some people, so consumption still largely relies on limited natural produce. Much of the decline in food security in many provinces in Indonesia is due to an increase in the share of household food expenditure. This is rapidly identifiable by several factors causing the decline in real household income. One of the causes of declining real household income is an increase in the prices of basic commodities, in this case particularly food items.

Figure 1 shows that many provinces experienced an increase in the share of food expenditure. This is not in line with the growing economic growth in Indonesia. Economic growth, one of which can be reflected in the increasing GRDP per capita of its people, which has a positive growth. However, this is not reflected in the declining share of public food expenditure. One of the other reasons for the occurrence of this phenomenon are the imbalance of regional development and income inequality of the community in various provinces in Indonesia. This is in line with what has been said by the World Bank that
Indonesia has experienced strong economic growth in the last 15 years, but most of the benefits enjoyed by the elite. The most Indonesian people think that the income distribution in Indonesia is "very unequal" or "not equal at all". This statement also shows how the dimensions of access become very important to consider in order to improve the food security of Indonesian society.

\section{Determinant Factor of Food Security in Indonesia}

As mentioned in the research methods section, the determinant factors affecting Indonesian food security will be analyzed using regression of binary logit with the category of food security variable as the dependent variable and some variables those are suspected to affect the Indonesia food security as independent variable. Some test taken to this model will be displayed below.

Table 2. Hosmer and Lemeshow Test

\begin{tabular}{lccc}
\hline Step & Chi-square & df & Sig. \\
\hline 1 & 5.76 & 8 & 0.674 \\
\hline
\end{tabular}

Source: Author calculation, 2017.

Table 2 shows that the test result has a Sig. value of 0.674 . This value is greater when compared with the agreed avalue of 0.05 . Therefore, it can be concluded that the established model has been appropriate and can be used for further analysis. 
Table 3. Coefficient Determination

\begin{tabular}{lccc}
\hline Step & $\begin{array}{c}-2 \text { Log } \\
\text { likelihood }\end{array}$ & $\begin{array}{c}\text { Cox \&Snell } \\
\text { R Square }\end{array}$ & $\begin{array}{c}\text { Nagelkerke } \\
\text { R Square }\end{array}$ \\
\hline 1 & 58.113 & 0.298 & 0.682 \\
\hline
\end{tabular}

Source: Author calculation, 2017.

Table 3 shows that from the analysis of determination has a value Nagelkerke $R$ Square of 0.682 . This value tells that the model made has variation of independent variable which can explain equal to $68,2 \%$ dependent variable and equal to $31,8 \%$ explained by other variables outside model. the regression model used has a good enough quality to be able to explain food security of Indonesia as its dependent variable.

Table 4. LR Test with Omnibus Test of Model Coefficient

\begin{tabular}{llccc} 
& & Chi-square & df & Sig. \\
\cline { 3 - 5 } Step & Step & 93.337 & 20 & 0.000 \\
1 & Block & 93.337 & 20 & 0.000 \\
& Model & 93.337 & 20 & 0.000 \\
\hline
\end{tabular}

Source: Author calculation, 2017.

Table 4 shows the results of the analysis that the independent variables in the model significantly influence the level of Indonesian food security simultaneously.

Table 5. Partial Test of Determinant Factors of Indonesian Food Security

\begin{tabular}{|c|c|c|c|c|c|c|c|}
\hline Variables in Equation & B & & S.E. & Wald & df & Sig. & $\operatorname{Exp}(B)$ \\
\hline Area_padfield & 0,000 & $* * *$ & 0 & 7.964 & 1 & 0.005 & 1,000 \\
\hline prod_paddy & 0,000 & $* * *$ & 0 & 8.8 & 1 & 0.003 & 1,000 \\
\hline prod_maize & 0,000 & $* *$ & 0 & 4.145 & 1 & 0.042 & 1,000 \\
\hline prod_soy & 0,000 & $* * *$ & 0 & 10.722 & 1 & 0.001 & 1,000 \\
\hline prod_cass & 0,000 & & 0 & 0.027 & 1 & 0.868 & 1,000 \\
\hline prod_chicken & 0,000 & $* * *$ & 0 & 7.859 & 1 & 0.005 & 1,000 \\
\hline prod_beef & -0.001 & $* *$ & 0 & 5.096 & 1 & 0.024 & 0.999 \\
\hline percent_unemployment & -0.011 & & 0.265 & 0.002 & 1 & 0.968 & 0.989 \\
\hline density_population & 0.019 & $*$ & 0.011 & 2.717 & 1 & 0.099 & 1.019 \\
\hline poor_number & -0.003 & & 0.004 & 0.389 & 1 & 0.533 & 0.997 \\
\hline grdp_cap & -0.133 & & 0.081 & 2.666 & 1 & 0.102 & 0.876 \\
\hline protein & -0.362 & & 0.254 & 2.027 & 1 & 0.155 & 0.696 \\
\hline cpi_foodstuff & -0.012 & & 0.047 & 0.063 & 1 & 0.801 & 0.988 \\
\hline Cpi_food & -0.029 & & 0.05 & 0.354 & 1 & 0.552 & 0.971 \\
\hline cpi_house_electricity_gas & -0.121 & $*$ & 0.07 & 3.011 & 1 & 0.083 & 0.886 \\
\hline cpi_clothes & 0.074 & & 0.052 & 2.043 & 1 & 0.153 & 1.077 \\
\hline cpi_health & 0.131 & $* *$ & 0.055 & 5.779 & 1 & 0.016 & 1.14 \\
\hline cpi_edu_sport_recre & -0.009 & & 0.024 & 0.149 & 1 & 0.699 & 0.991 \\
\hline cpi_trans_services_finance & 0.141 & $* *$ & 0.062 & 5.166 & 1 & 0.023 & 1.151 \\
\hline FIMI & -0.745 & $* *$ & 0.292 & 6.525 & 1 & 0.011 & 0.475 \\
\hline Constant & 50.006 & & 24.594 & 4.134 & 1 & 0.042 & $5.22 \mathrm{E}+21$ \\
\hline
\end{tabular}

Note: * significant on $\alpha=10 \%$

$$
\begin{aligned}
& * * \text { significant on } \alpha=5 \% \\
& * * * \text { significant on } \alpha=1 \%
\end{aligned}
$$

Source: Author calculation (2017) based on secondary data. 
This decision is based on the significance value on the Model line of 0.000 . This value is smaller than the error rate constant $\alpha$ of 0.05 . The results of this test indicate that the model can reasonably be used to estimate the factors that affect the level of Indonesian food security.

Some variables in the model as a representation of dimensions of food availability such as land area, paddy production, maize production, soybean production, chicken meat production and beef production significantly influence the level of food security in Indonesia at error rate of $5 \%$. These variables besides beef production have a positive expectation sign. This means that the more widely available paddy fields will improve the level of food security in Indonesia. Variable area of paddy field has a ratio value of 1 . This value means that if the width of paddy fields in Indonesia increases 1 unit it will increase the food security of Indonesia as much as 1 times better than before. The same interpretation also applies to rice production variables, corn production, soybean production and chicken production in Indonesia. That, each increase of one unit in each of these variables will increase food security in Indonesia 1 times better.

In contrast to chicken meat, beef production in the regression analysis shown in Table 4 shows a negative relationship to Indonesia's food security status. Of course, this phenomenon cannot be interpreted simply by looking at the results of the analysis. After seeing the distribution of beef production data in each province over the years, it was found that some of the largest cattle production centers in Indonesia were on average in the category of food insecurity (including three dimensions of Jonsson and Toole food security after food secure) such as Aceh province, East Kalimantan, NTT, and several other provinces. The beef production variables have a strong and negative relationship with maize production, soybean production, and chicken production, where the three variables have a significant effect on food security status with positive value. This tells us that in general cows are developed in areas that have low crop production.

Cattles are widely developed by farmers in grassland, mountains, and various marginal lands that contain enough feed and become an alternative source of income for farmers who cannot maximally develop food crops. In fact, beef production will have a market and widely consumed by the upper middle class who mostly live in urban areas and big cities in Indonesia that in fact have no beef production. Thus, beef production in a province can generally improve the food security of Indonesian people, but not necessarily improve the quality of food consumption in the central provinces.

The population density variable has a significance value of 0.099 with a positive expectation mark. That is, the 
population density variables significantly influence the food security of Indonesia $10 \%$ error rate. The sign of the regression coefficient on this variable is contrary to the expectation sign. Some theories say that population density will cause the ratio of food availability to consumption is less so that will reduce the level of food security.

A deeper review of the data found that provinces with high population densities had better food security levels than other provinces. This is further demonstrated through data on the first objective analysis of provinces in Sumatra and Java, which in fact have high population density, have better food security when compared to some areas in Sulawesi, Nusa Tenggara and Papua with low population density. This can be explained because areas with high population density reflect areas of economic growth centers. People living in this area on average have better economic capabilities to access various food and non-food needs than people living in other areas. Especially the need for food despite having a low ratio to consumption but can be offset by bringing in from other areas that have surplus.

Table 4 also shows the existence of several variables representing the dimension of food stability which has significant effect to the level of food security in Indonesia. The CPI of electric and gas housing significantly affected the error rate of $10 \%$ and has a positive regression coefficient. That is, increasing prices on these types of goods and services will reduce the level of food security in Indonesia. As with the CPI health and CPI services and financial services are both significantly affected at a 5\% error rate with positive signified regression coefficients. Rising prices of non-food goods and services will directly affect the decline in the share of household food expenditure so as to shift food security. this needs to be further explored whether the decline in the share of household food expenditure is followed by improving their welfare.

FIMI became one of the variables used in the model as an independent variable to prove some theories and previous studies that the level of food insecurity can be used as a means of measuring the level of food security. An area that has a high FIMI value tells that there has been food insecurity that is high enough so that it has a low level of food security. The FIMI variable in the model significantly influences Indonesian food security level at 5\% error rate with negative value regression coefficient. That is, the higher the FIMI value will actually show the low level of food security of Indonesia. If this value increases 1 unit, it will decrease the level of food security of Indonesia 0.475 times than the original state.

\section{CONCLUSION AND SUGGESTION}

Based on the results of this research, it can be concluded that there are 11 
variables that influence significantly to food security of Indonesia a total of 20 suspected variables. Beef production, the CPI of housing, electricity and gas and FIMI variable has negative significant influences. It means those variables are the influential factors on the decline level of food security in Indonesia. While Land area, rice production, corn production, soybean production, chicken meat production, the population density, the health $\mathrm{CPI}$, the CPI transportation and financial services have positive influences toward food security Indonesia. It means those variables are the influential factors on increase level of food security in Indonesia. Raising food security can be achieved by attention and increase the quality of food distribution especially in areas with high food deficit level (low production especially for staple food). There needs to be increased in the government's food reserve program, especially at the district level, which is adjusted to the ratio of production and consumption of the community whose costs are included in the Regional Government Budget to reduce the risk of food deficit and food price fluctuations, especially staple foods.

There is need for socialization and strategies to improve the quality of consumption through socialization and improving the welfare of the community through various programs and policy to control prices including good and services, it can improve calorie intake and economic access capacity of the community and reduce the income gap of community and also legal strengthening and assertiveness of policy implementation in protecting wetland conversion, and efforts to increase production quantity through intensification and extensification of farming. Food security can be held by not only improve the quantity and quality of consumption, but also improve the food supply, the ability to access economically, and stable over time.

\section{REFERENCES}

Abbade, Eduardo Botti and Homero Dewes. 2015. Food Insecurity Worlwide Derived from Food Supply Pattern. Springer Science \& Business Media Dordrecht and International Society for Plant Patology. Food insecurity and food supply pattern (7): 109-120.

Barret, Christhoper B. 2010. Measuring Food Insecurity. Science 327 (5967): 825-828.

Bayaga, Anass. 2010. Multinomial Logistic Regression: Usage and Application in Risk Analysis. Journal of Applied Qualitative Method 5 (2): 288-297.

Bush, R. 2010. Food Riots: Poverty, Power and Protest. Journal of Agrarian Change (10): 119-129.

Enisan, Akinlo A. and Akinlo O.Olufisayo. 2009. Stock Market Development 
and Economic Growth: Evidence from Seven Sub-Sahara African Countrie. Journal of Economics and Business (61): 162-171.

Food Security Council RI.2009. Peta Ketahanan dan Kerentanan Pangan Indonesia. Jakarta: Dewan Ketahanan Pangan, Departemen Pertanian RI and WFP.PT Enka Deli.

Genest, Christian, Bruno Remilard, and David Beaudoin. Goodness-of-fit tests for copulas: A review and a power study. Insurance: Mathematics and Economics 44 (2): 199-213.

Groom, Ben. 2015. Welfare Analysis of Changing Food Price: a Nonparametric Examination of Rice Policies in India. Springer Science \& Business Media Dordrecht and International Society for Plant Patology. Food insecurity and food supply pattern 7 (1): 121-141.

Lantarsih, R., Widodo, S., Darwanto, D. H., Lestari, S. B., dan Paramita, S. 2011. Sistem Ketahanan Pangan Nasional: Kontribusi Ketersediaan dan Konsumsi Energi Serta Optimalisasi Distribusi Beras. Jurnal Analisis Kebijakan Pertanian 9(1): 33-51.

Maxwell, D., Levin, M. A. Klemeseu, M. Rull, S. Morris and C. Aliadeke. 2000. Urban Livelihoods and Food
Nutrition security in Greater Accra, Ghana. Washington D.C: IFPRI in Collaborative with Noguchi Memorial Research and World Health Organization. Research Report No. 112.

Mulyo, J. H., Sugiyarto, Arif W. W. 2015. Household's Food Security and Food Self Sufficiency in the Rural Marginal Area of Bojonegoro Regency. Jurnal Agro Ekonomi26 (2): 121-128.

Nanggolan, K. 2007. Program dan Kegiatan Ketahanan Pangan Tahun 2008. Jakarta: Musyawarah Pembangunan Pertanian Nasional.

Omotesho, O.A., Adewumi, dan Fadimula. 2010. Food Security and Poverty of the Rural Households in Kwara State, Nigeria. Libyan Agriculture Research Center Journal International1 (1): 56-59.

Saliem, J.P, Mardiyanto, S. and Simatupang, P., 2003. Perkembangan dan prospek kemandirian pangan nasional. Jurnal Analisis Kebijakan Pertanian 1 (2): Juni 2003.

Zezza, Alberto and Luca Tasciotti. Urban Agriculture, Poverti, and Food Security: Empirical Evidence fom a sample of Developing Countries. Food Policy 35 (4): 265-273. 